\title{
Research
}

\section{Cultural or Ecological Sustainability? The Effect of Cultural Change on Sabal Palm Management Among the Lowland Maya of Mexico}

\author{
$\underline{\text { Andrea Martínez-Ballesté }}^{1}, \underline{\text { Carlos Martorell }}^{1}$, and Javier Caballero $^{1}$
}

\begin{abstract}
Sabal palm has been used for thatching the traditional Maya house for over $3000 \mathrm{yr}$. The great importance of this resource has promoted its management within home gardens. Although traditionally managed populations in home gardens are capable of ecological long-term persistence, the impact of cultural change on sustainable resource management is poorly understood. By means of interviews in 108 households, we obtained information about Sabal management practices, leaf demand, and sociocultural data. Density and size structure of the palm populations in the respective home gardens were also measured. By means of principal components analysis, the sociocultural data were summarized into a cultural change index, which was then statistically related to palm density, size structure, leaf demand, and management practices. Leaf demand along the cultural change gradient was estimated. Sabal populations were affected by the cultural change index. Palm density and the proportion of harvestable individuals were higher in the more traditional households. The number of management practices decreased, and the probability of felling adult palms increased with cultural change. As a result, the percentage of the total leaf demand satisfied by home garden production diminished from 118.2-69.4\% as cultural change increased. Traditional practices seem oriented to increasing the palm availability. Seed sowing and the protection of seedlings and adults affect the life stages with the largest impact on the population growth rate, as measured through sensitivity analysis. This means that abandoning traditional practices and felling adults more frequently should reduce rapidly, which is consistent with the low palm density observed in less traditional households. The application of demographic models to Sabal tells us that traditional management warrants the persistence of the resource as long as the current conditions remain unchanged. In contrast, our data show that Sabal management may not be sustainable from a cultural perspective, since the cultural attitudes that affect palm management and demand change over time. Both approaches assess the same problem from different viewpoints reaching different but complementary conclusions. In this study, we propose new methods that integrate the ecological and cultural processes, which affect the sustainable management of the natural resources.
\end{abstract}

Key Words: cultural change; ethnoecology; Maya; Mexico; Sabal; traditional management.

\section{INTRODUCTION}

Traditional strategies in the management of natural resources are based on the local knowledge about biological systems (Berkes et al. 2000), but also respond to historical, economic, social, and cultural factors (Caballero 1994, Balée 1998, Hertog and Wiersum 2000, Ruiz-Pérez et al. 2004). Culture, understood as a conceptual scheme encoding social behavior, mediates human action including decisions on what and how to manage biological resources and transform ecosystems (Boas 1938, Vayda 1983, Yengoyan 1986, Berlin 1992).
However, culture is not static but it is daily constructed in such a way that social behavior, as well as the social structures that maintain the identity of a human group, may be frequently altered. Cultural practices such as marriage ceremonies, the way in which a house is built, or the particular way in which a plant resource is used and managed, become relatively distinct cultural traditions as they are passed down through generations. These types of cultural practices are the main units in which cultural change operates (Goodenough 2003). The shared knowledge about resource-management practices may, therefore, be 
modified as a result of these processes of cultural transformation (Padoch and De Jong 1992, Freeman 2002).

Sustainability science is a new field in search of understanding the fundamental interactions between nature and society (Kates et al. 2001). It has been proposed that only through the development of qualitative and quantitative research, which recognizes the complexity and uncertainties of environmental and social systems, will the sustainability of biological resource management be successfully evaluated (Swart et al. 2002). From an ecological point of view, studies on sustainability are focused on assessing the longterm maintenance of the system's productivity (Lubchenco et al. 1991), but few studies with this approach have incorporated other factors that could affect such systems (Joyal 1996, Ticktin et al. 2002). The impact of cultural change on sustainable resource management is poorly understood. From a qualitative perspective, cultural change and its effects on resource management have been documented by anthropological studies from the observation of change in resource management through time (Kottak 2004). From the ecological point of view, the effect of cultural change on the sustainability of biological systems has been discussed by a number of scholars (Schmink et al. 1992, Almeida 1996, Rocheleau 1999), but there are no quantitative case studies assessing to what extent transformation or abandonment of management practices resulting from cultural change may affect the sustainability of a resource.

Based on previous work, we know that the management of the $x a$ 'an palm (Sabal yapa Wright ex Becc. and Sabal mexicana Mart., Arecaceae) in home gardens by the most culturally conservative Mayas in the Yucatan peninsula is ecologically sustainable, since demographic models project that palm populations are capable of persisting under the current management conditions (Martínez-Ballesté et al. 2005). The leaves of both palm species have been harvested since Pre-Columbian times for thatching purposes, and the form of use has remained practically unchanged until today. Thus, present-time Maya houses are still much like those that were built about 1000 B.C. Furthermore, studies on the perception and linguistic classification of Sabal show that this resource has been extremely important for the Maya for over $3000 \mathrm{yr}$ (Caballero 1994).
To assure or to promote the availability of Sabal palm, it has been managed under a number of different systems. Formerly gathered in the wild, other management forms were developed as a response to population growth and the decreasing availability of these palms in the wild as a result of historical changes in land use (Caballero 1994). One of the most widespread management strategies in the Yucatan Peninsula, dating back to the colonial period, is the tolerance and even promotion of Sabal within home gardens (Caballero 1994). This complex agroforestry system is a dynamic space in constant transformation in which families manage, according to their preferences, a great variety of both wild and cultivated trees and shrubs. Management of Sabal in home gardens increases palm density, as well as the proportion of harvestable-sized individuals, thus increasing the availability of this resource in regions where the natural vegetation that provided the palm in the past has been reduced (Martínez-Ballesté et al. 2002).

Over the past few decades, cultural change processes among the Maya of Yucatan have been strongly influenced by the economic changes in the region. The rapid expansion of the tourists industry, as well as the trend of younger generations to abandon agriculture, have lead to an increasingly widespread loss of the traditional knowledge on Sabal palm (Caballero 1994). According to Thompson (1976), the cultural differences in this area are best represented in terms of economic an educational factors. Thompson recognized a cultural change gradient forming a continuum between two extremes that are best represented by two ethnic groups: the less traditional Catrines, which includes both former Maya and nonindigenous populations, especially descendants of the Spaniards that colonized Yucatan. They are relatively wealthy people, and are considered to have a high status in the society. They do not regularly participate in guilds and religious sodalities, have studied for more years, and are devoted to market-oriented activities. The members of the other group, the more traditional Mestizos, have a Maya origin. They are less wealthy and have less prestige in the society; they are devoted to subsistence agriculture, and have studied for fewer years. Between the extremes of this gradient of sociocultural change, there are wide variations in the factors that define each group. According to Thompson, this gradient reflects the prevalent mode of ongoing cultural change. Even though there is an opposition to this process among the Maya, the 
change prevails, and the generalized trend among the Mestizos is to become Catrines. This process involves the change in cultural attitudes and the adoption of new symbols of status. The replacement of traditional palm-thatched houses by cardboard or concrete roofs may be an example of this process. This change may be associated to the loss of traditional knowledge on the palm management practices and to the abandonment of the latter.

Although traditionally managed palm populations in home gardens are capable of long-term persistence (Martínez-Ballesté et al. 2005), the loss of biological knowledge and perception of cultural importance may modify management practices, resulting in the reduction of the resource base. The study of the management of Sabal in home gardens in a context of social transformation is an appropriate system to test whether there is a relationship between cultural change and the sustainability of the resource management. Based on the above, this research assesses the relationship between cultural change, management, and demographic parameters of the Sabal palm, testing the hypothesis that cultural change limits the achievement of ecological sustainability in home gardens.

\section{METHODS}

\section{Study area}

This study was conducted in the southwestern portion of the State of Yucatan, Mexico. Nine towns in which Sabal is managed in home gardens were selected (Fig. 1). Following Thompson (1976), to assure the sampling interviewing householders with different degrees of cultural change we chose three traditional villages, i.e., Calcehtok, Yotholín, and Chicán, which are mostly inhabited by peasants who have little formal education 4.29 schooling $\mathrm{yr}$ on average, three highly acculturated towns, i.e., Maxcanú, Ticul, and Tekax, in which people are mostly involved in market economy and have gone to school for a longer period of time $\sim 6.31$ schooling yr, and three towns, i.e., Opichén, Maní, and Tixméuac, with intermediate characteristics.

\section{Field work and data analysis}

A random sample of 12 households was selected in each town, 6 with a few palms or none at all, and 6 with many palms, based on a visual appreciation. By means of structured interviews in each household, we obtained information about Sabal management practices, preferences and leaf demand for roof thatching, and socioeconomic data, e.g., occupation, educational level, knowledge of Spanish and Maya languages, income, government support, etc. Information about density and size structure of the palm population in each home garden was obtained by randomly established plots measuring $20 \mathrm{~m}$ long by 1,3 , or $6 \mathrm{~m}$ wide according to palm size, as well as complete censuses in home gardens with a only few palms. Seedlings were not counted. Individuals were classified into nonharvestable saplings, harvestable juveniles, and adults too large to be harvested.

To summarize the socioeconomic differences among the 108 interviewed households, we applied a principal component analysis (PCA). This analysis was used to synthesize the characteristics that contributed the most to classify families. The first principal component was interpreted as a cultural change index. For simplicity purposes, the PCA scores were transformed to a scale ranging from 0 to 100 . Using generalized linear models, the cultural change index was related to palm density, proportion of saplings, juveniles and adults, number of palm-thatched houses and kitchens, and management practices such as the probability of sowing palms, the number of palm-care practices carried out by the landowner, the proportion of adult palms felled in the last $5 \mathrm{yr}$, the presence of Sabal in other holdings owned by the householder, the probability of harvesting wild palms, the probability of selling, buying, or giving away leaves, and the per-palm individual harvesting intensity. People did not clearly remember the number of felled small palms. Thatching material preference and the reasons for adult felling were related to cultural change by means of independence $\chi^{2}$ tests followed by Haberman's adjusted residuals analysis (GreigSmith 1983).

To assess the biological soundness of the traditional management practices mentioned in the interviews, we used the demographic data obtained in two home gardens in Maxcanú. Demographic data were available as matrix population models (MartínezBallesté et al. 2005). We calculated the mean matrix 
Fig. 1. Location of the study sites. We chose three traditional villages: Calcehtok (1), Yotholín (2), and Chicán (3), three highly cultural change towns Maxcanú (4), Ticul (5), and Tekax (6), and three towns with intermediate characteristics Opichén (7), Maní (8), and Tixméuac (9).

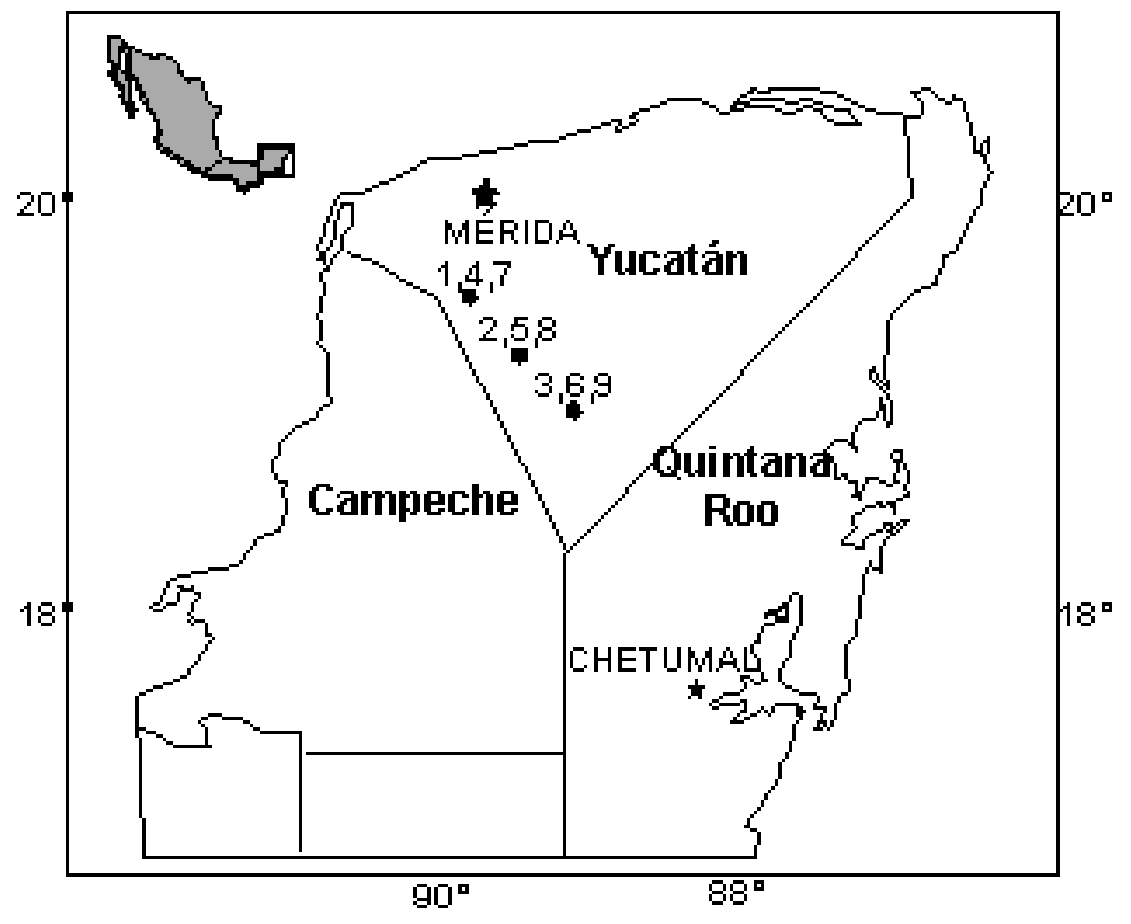

for each home garden and species and performed a sensitivity analysis, which estimates impact that small modifications in the vital rates have on the population growth rate $(\lambda)$ (Caswell 2001). If management is appropriate, it should be directed to care the most sensible life stages. In both home gardens we also counted the number of leaves produced every year by harvestable-sized palms. This number was used to estimate the leaf production of different home gardens by multiplying it by the number of harvestable palms that were present there.

To assess whether leaf production satisfies the needs of the householders along the gradient of cultural change, we reanalyzed data from 45 interviews on the demand for Sabal leaf conducted by Gama (2001). Assuming that buildings are thatched asynchronously, and that the rate of construction remains constant over the time, the roof age should follow a uniform distribution. From the formula for the expected value (Freund and Walpole 1987) it can be shown that

$$
\begin{aligned}
& \bar{a} \cong \mathrm{E}(a)=\frac{r_{\mathrm{t}}}{2} \\
& \mathrm{r}_{\mathrm{t}} \cong 2 \overline{\mathrm{a}}
\end{aligned}
$$

Where $a$ is the age of the roof at the moment of the interview, and $l_{t}$ is the average life span of a roof. The average number of leaves needed yearly to complete roof renewal, $N_{t}$, was estimated by dividing the average number of leaves in a roof by $l_{t}$. Based on a two-year census of 60 households, the average annual demand for repairs was estimated by Pulido and Caballero at 53.62 leaves for houses and 11.89 for kitchens. The overall household leaf demand was then calculated by multiplying the number of thatched structures, estimated by means of a regression of the number of houses and kitchens on the cultural change index, by the per-building leaf demand. We calculated the total production of 
leaves/household using the mean area of a home garden, the regressions of palm density, harvestable-individual proportion on cultural change level, and leaf-production data.

\section{RESULTS}

\section{Socioeconomic variables}

The 108 families interviewed were distributed along a continuous gradient in the first principal component, which explained $36 \%$ of the variation in the socioeconomic data. The largest loadings were related to the family's activities, average number of school years/family, the proportion of family members that speak fluent Spanish, ownership of maize fields, as well as main occupation and number of school years attended by the head of the household (Table 1). Families with a low schooling level and less Spanish fluency, who were involved in subsistence economy and maize cultivation, were found in one extreme of the ordination axis. These households were considered to be the most traditional ones. A zero value in the cultural change index was assigned to the most traditional of these householders. To the other extreme, a family whose head had a Masters of Sciences degree, and who worked as high-school principal, received and cultural change value of 100 .

\section{Management practices}

The management of Sabal palms was affected by the cultural change index. The practice of sowing palms in the home garden was significantly more common in traditional households $\left(\chi^{2}=10.36, P=\right.$ $0.0013, R^{2}=10.36 \%$; Fig. $\left.2 \mathrm{a}\right)$. The number of management practices (Fig. 2b) decreased with cultural change $\left(\chi^{2}=4.21, P=0.0400, R^{2}=\right.$

$4.21 \%)$. Although the families with the most cultural change mentioned a few management practices or none at all, traditional Mayas reported protecting seedlings from grazing and burning, combating pests, harvesting leaves on a regular basis, avoiding palm felling, and weeding and watering the home garden to promote palm growth.

The felling rate of adult palms (Fig. 2c) increased with cultural change $\left(F=6.16, P=0.0150 R^{2}=\right.$ $6.36 \%$ ). When traditional Mayas knock down an adult individual, they do it mostly because it is old and represents a danger to the family, but families with more cultural change fell adult palms because they need the land for other uses considered more important, such as livestock rising and the building of new houses $\left(\chi^{2}=6.55, P=0.0370\right)$. The ownership of other lands from which $x a$ 'an may be extracted, harvesting wild palms, and the per palm leaf-extraction intensity were not significantly related to the cultural change index.

From the demographic data we found that seedling growth, as well as the adult palm survival and growth, were the most sensitive categories (Appendix). The population growth rates observed for $S$. mexicana were $\lambda=1.04(0.98,1.12,95 \%$ confidence interval) and $\lambda=0.983(0.93,1.04)$, and for $S$. yapa $\lambda=1.007(0.92,1.09)$ and $\lambda=1.092$ $(0.99,1.19)$.

\section{Demographic parameters}

Palm density is higher in the more traditional home gardens $\left(F=3.84, P=0.0076, R^{2}=10 \%\right)$, where it reaches some 900 palms/ha, whereas the householders with more cultural change keep only $200 \mathrm{palms} / \mathrm{ha}$ (Fig. 2d). Around 50\% of the individuals were harvestable juvenile palms in the more traditional home gardens, in contrast to only $20 \%$ in the opposite case $(F=4.08, P=0.0460$, $R^{2}=4.21 \%$; Fig. 2e). Regressions of the fractions of saplings and adults on cultural change were not significant.

\section{Leaf demand and exchange}

We found that more traditional families constructed significantly $\left(\chi^{2}=20.62, P<0.0001\right)$ more palmthatched houses (Fig. 2f) and kitchens $\left(\chi^{2}=7.72\right.$, $P=0.0054$; Fig. $2 \mathrm{~g}$ ), whereas the families with more cultural change had more concrete or cardboard roofs. We estimate that a house needs an average of 144.4 leaves/yr for thatch repairs and complete renewal, whereas a kitchen needs just 69.8 leaves. From our estimates of harvestable palm density, and using the observed average production of 5.28 leaves/harvestable palm, we found that all families produced more than enough leaves for repairs. The surplus in traditional home gardens may then be used for complete roof renewal, but it is not enough for the less traditional families. The percentage of the total leaf demand for repairs and renewal satisfied by home garden leaf production diminishes 
Fig. 2. Relationship between cultural change index and management practices, demographic parameters, and leaf demand. In a) probability of planting new palms, b) number of mentioned management practices, c) probability of felling adult palms, d) palm density/ha, e) percentage of harvestable-size palms, f) number of houses thatched with Sabal palm, and g) number of kitchens thatched with Sabal palm. Dots show the observed values, and lines show the tendency obtained from the generalised lineal models.
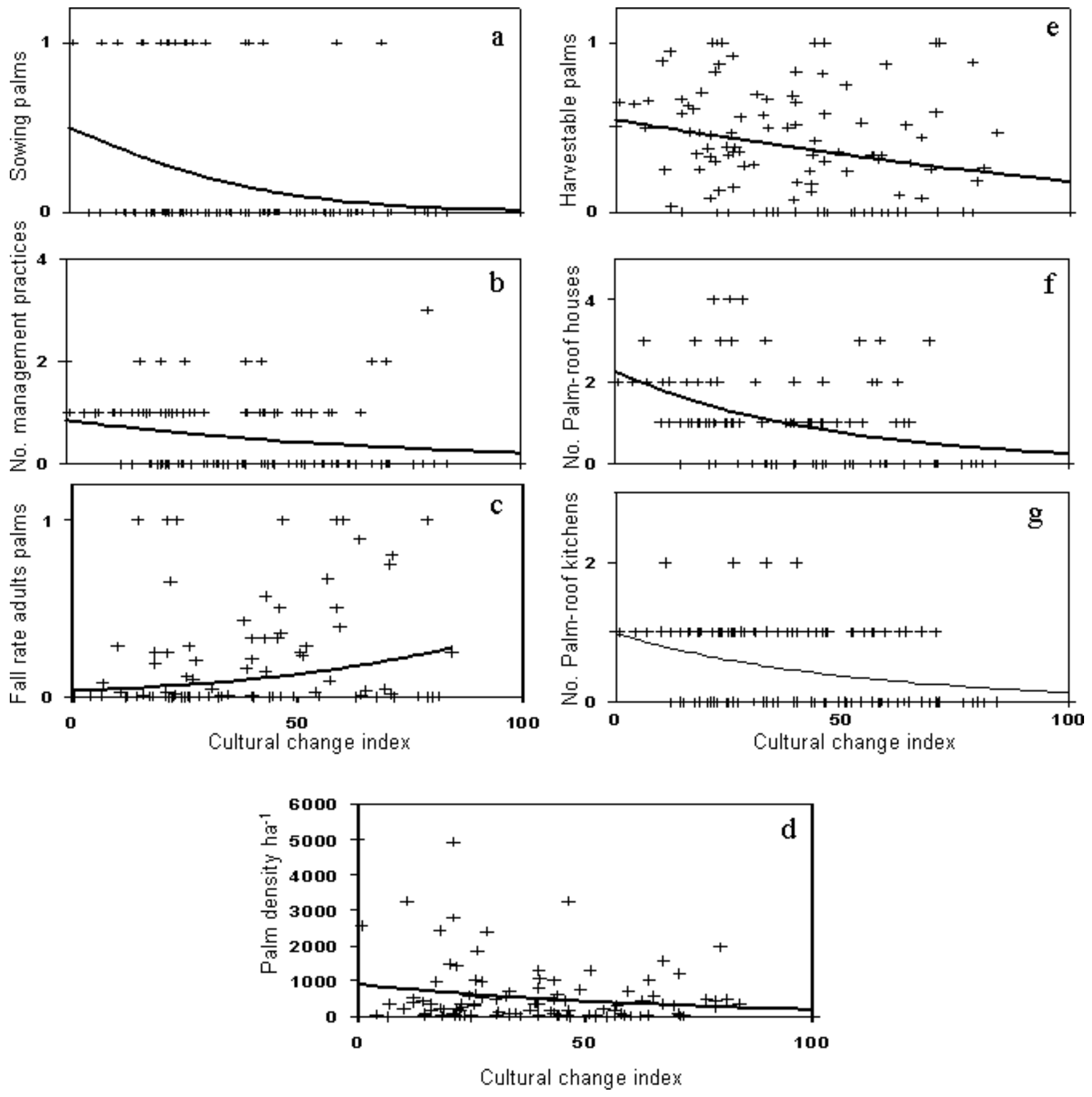
Table 1. Principle components analysis (PCA) variable loadings in Axis 1. The most important socioeconomic characters, which ordained the 108 interviewed families, are shown in bold numbers.

\begin{tabular}{lc}
\hline \hline PCA variables & PC1 loadings \\
\hline Family occupation & $\mathbf{- 0 . 3 6 5}$ \\
Family education & $\mathbf{- 0 . 3 2 2}$ \\
Maya language (\%) & 0.212 \\
Spanish language (\%) & $\mathbf{- 0 . 3 3 6}$ \\
Familiar income & -0.237 \\
Foreign income & 0.006 \\
Government support & 0.170 \\
Maize field ownership & $\mathbf{0 . 3 2 3}$ \\
Householder occupation & $\mathbf{- 0 . 3 6 7}$ \\
Householder secondary occupation & 0.206 \\
Householder education & $\mathbf{- 0 . 3 0 1}$ \\
Householder language & -0.255 \\
Cornershop ownership & -0.097 \\
\hline
\end{tabular}

from 118.2-69.4\% as cultural change proceeds (Fig 3). Activities such as commercialization, i.e., probability of selling and buying, and exchange of leaves among families, as well as preferred roofing materials, showed no significant relation to the cultural change index.

\section{DISCUSSION}

Results of this study show a close relationship between cultural change and leaf demand and manipulation of Sabal palms. Occupational prestige, educational level, and fluency in Spanish were the most important variables in the households' ordination. This is in close agreement with Thompson's (1976) proposal that the more traditional families are involved in agricultural labor, have less formal education, and are less fluent in Spanish, whereas the opposite occurs in the case of the families with the most cultural change.

Our results suggest that the practices carried out by the more traditional households, which need more leaves, promote the increase in palm availability. Practices such as palm sowing and the protection of seedlings and adults, positively affect the survival and permanence of both life stages. These demographic rates are the ones with the largest impact on the population growth rate $(\lambda)$ as

measured through sensitivity analysis. The special attention paid to seedlings was found to increase Sabal yapa's annual population growth rate by $1.4 \%$ in home gardens when compared to management forms where no seedling protection occurs (Martínez-Ballesté et al. 2005). By avoiding felling adult individuals, the traditional householders may make an important contribution to the persistence of palm populations in their home gardens. As a result, traditional management may 
Fig. 3. Percentage of annual leaf demand that was fulfilled by the 108 interviewed families.

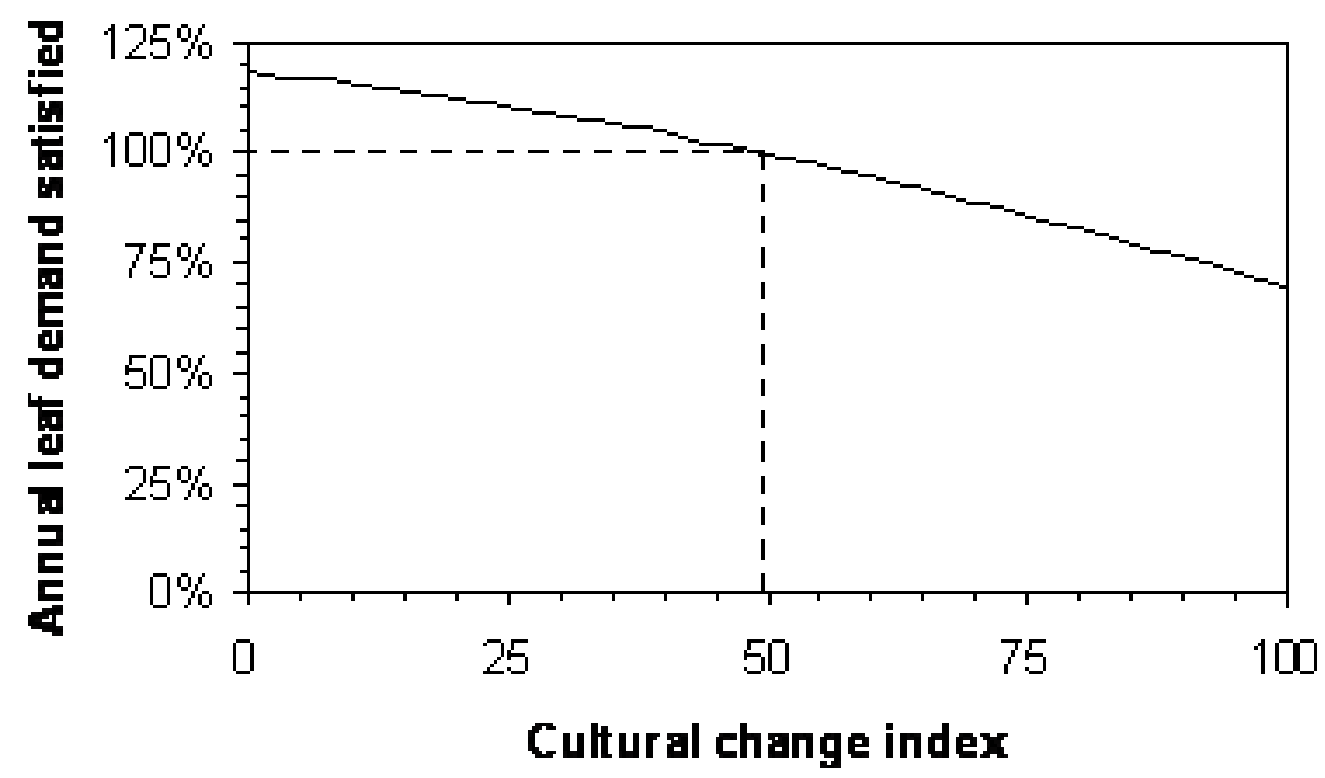

be sustainable as shown by the $\lambda$ 's above unity observed in the two home gardens, which had cultural change indices of 15 and 35 (MartínezBallesté et al. 2005).

Current change in cultural attitudes entails abandoning traditional palm management practices. Families with a higher degree of cultural change do not protect small palms and fell the adults more frequently. This may have a negative impact on $\lambda$. Even though we have no direct measurements of this parameter for the 108 home gardens, the reduction in palm density occurring as cultural change process means that there must be a negative growth of the palm population over time.

Traditional practices also have an impact on the population structure of palms. Although less traditional families keep the juvenile proportion as low as $20 \%$, the more traditional householders increase this proportion up to $50 \%$. By doing so, the traditional Maya maximize leaf production through an increased density and proportion of harvestable individuals. As a result, they meet their needs for thatch repairs and are capable of producing all the leaves they require for complete roof renewal.
The reduced leaf-production in the home gardens of less traditional householders most certainly responds to a reduction in their leaf demand. However, production diminishes faster than the demand, as evidenced by the reduction of the needs that are satisfied from 118-69\%. Main occupation of less traditional Maya households tends to be more related to market-oriented activities, so they may lack interest in achieving self-sufficiency as their domestic economy is oriented to acquiring rather than to producing. Even though we found no correlation between culture and commercialization, i.e., the probability of selling, buying, or giving Sabal leaves, the reduced domestic leaf production makes less traditional people buy at least a part of the palm leaves they need.

A rise in schooling years from 5 to 6.8 , and a reduction of $10 \%$ in the fraction of the economically active population involved in agriculture has occurred in Yucatan over the past 10 yr (INEGI 1990, 2000), suggesting a widespread sociocultural transformation of the Yucatec population. Nevertheless, the number of thatch-roofed houses in the state of Yucatan has remained nearly the same, falling only from 44,267 to 42,325 (INEGI 1990, 2000). If the pattern found in this study is 
generalized, the production of Sabal leaves may probably be decreasing although the demand for thatched-roof houses in Yucatan has not changed much over the past 10 years. With a decrease in resources, some of the poorest inhabitants with a cultural change index of $60-80 \%$ have substituted the use of palm leaves for cardboard. Peasants with enough palms in their home gardens prefer not to sell, but when they occasionally do, the prices of the leaves are so high that roofing with cardboard becomes the cheapest alternative.

Several scenarios may result from a reduction in leaf production at the home gardens. Tacking into account that leaf demand is still relatively high, it is possible that new management forms, such as plantations, evolve to satisfy the needs of the Maya families, or the harvest of the remaining palms may be intensified to meet the demand. Another possibility is that palm thatching is abandoned; substituting palm leaves for other materials as it is currently occurring. However, our low $R^{2}$ values do not allow us to make any projections for the future. These values suggest that there are other variables affecting the demographic parameters that we measured. Certainly the Sabal populations do not respond immediately to changes in cultural attitudes entailing changes in plant resource management, even if these are as large as those that occur when a home garden is sold to new owners. Also, the different members of a household frequently own different parts of the home garden and make decisions on the palms therein. These processes may cause a lack of fit between cultural and demographic parameters as we measured them. The inclusion of different towns in this study also affects our results, since there are economical, historical, or cultural differences among them that affect the way home gardens are managed. While this reduces the fit of the models, it increases their representation, establishing a widespread trend. Nevertheless, a relatively weak relationship may have a large effect over large time scales.

Sustainable use, from an ecological perspective, may be achieved if the management of a resource allows its natural replacement, so it is capable of renewing itself indefinitely (Mangel et al. 1993). The ecological processes and practices that affect a managed population have been integrated into the demographic assessment of sustainability (Ticktin 2004). However, culture has not been taken into account, probably because of the daunting task of turning it into numbers amenable of a mathematical treatment compatible with demographic models. Cultural change is, nevertheless, a dynamic process. Since cultural attitudes affect management and demand in households, cultural change is a flagrant deviation from the assumptions of unchanging environment and management made in most of the demographic models used in research. The application of these models to Sabal tells us that home garden-managed populations are biologically sustainable (Martínez-Ballesté et al. 2005). Our data show that, from a cultural perspective, they may be not sustainable.

Although we have discussed our results stressing out the differences among the most and less traditional households, we must bear in mind that, as our results point out, these are just the extremes of a cultural change gradient. Cultural change is a complex, continued and gradual process, and many aspects of it certainly escaped our quantitative approach. However, the new method proposed here allowed us to relate successfully the interacting ecological and cultural processes affecting the sustainability of the productive systems. Other factors must be included in future research in order to acquire a better understanding on the sustainable use of a resource that has been historically important for the Maya of Yucatan.

Responses to this article can be read online at: http://www.ecologyandsociety.org/voll1/iss2/art27/ responses/

\section{Acknowledgments:}

The present study was funded by CONABIO (Project M111), CONACyT (Project 31846-B), which along with the Universidad Nacional Autonoma de México, also gave a Ph.D. grant to the first author. The 108 families who allowed us to work in their lands and always welcomed us affectionately. We also wish to thank the logistic support of municipal authorities of the nine villages, of Salvador Flores and Juan Tun at the Universidad Autonoma de Yucatán, and of the Botanical Garden and Biology Institute of the Universidad Nacional Autónoma de México. María del Carmen Mandujano, and Miguel Martínez-Ramos made valuable comments on this study. 


\section{LITERATURE CITED}

Almeida, M. W. B. 1996. Household extractive economies. Pages 119-141 in M. Ruiz-Pérez and J. E. M. Arnold, editors. Current Issues in Non-Timber Forest Products Research Center for International Forestry Research, Bogor, Indonesia.

Balée, W. 1998. Historical ecology: premises and postulates. Pages 13-29 in W. Balée, editor. Advances in Historical Ecology Columbia

University, New York, New York, USA.

Berkes, F., J. Colding, and C. Folke. 2000.

Rediscovery of traditional ecological knowledge as adaptive management. Ecological Applications 10 (5):1251-1262.

Berlin, B. 1992. Ethnobiological classification: principles of categorization of plants and animals in traditional societies. Princeton University Press, Princeton, New Jersey, USA.

Boas, F. 1938. The mind of primitive man. MacMillan, New York, New York, USA.

Caballero, J. 1994. Use and management of Sabal palms among the Maya of Yucatan. Dissertation. University of California, Berkeley, California, USA.

Caswell, H. 2001. Matrix population models: construction, analysis, and interpretation. Sinauer Associates, Sunderland, Massachusetts, USA.

Freeman, D. 2002. Initiating change in highland Ethiopia: causes and consequences of cultural transformation. Cambridge University Press, New York, New York.

Freund, J. E., and R. E. Walpole. 1987.

Mathematical statistics. Prentice Hall, Englewood Cliffs, New Jersey, USA.

Gama, V. 2001. Demanda y Disponibilidad de la Palma de Guano (Sabal spp., Arecaceae) en tres Comunidades de la Península de Yucatán. Thesis. Universidad Nacional Autónoma de México, México, Mexico.

Goodenough, W. H. 2003. In pursuit of culture. Annual Review of Anthropology 32:1-12.

Greig-Smith, P. 1983. Quantitative plant ecology.
Blackwell, Oxford, UK.

Hertog, W. H., and K. F. Wiersum. 2000. Timur (Zanthoxylum armatum) production in Nepal: dynamics in nontimber forest resource management. Mountain Research and Development 20 (2):136-145.

Instituto Nacional de Estadística Geografía e Informática, México (INEGI). 1990. Yucatán, resultados definitivos. Datos por localidad. XI Censo general de población y vivienda, 1990.

INEGI, Mexico, Mexico.

Instituto Nacional de Estadística Geografía e Informática, México (INEGI). 2000. Yucatán, resultados definitivos. Datos por localidad. XII Censo general de población y vivienda, 2000.

Instituto Nacional de Estadística Geografía e Informática, México. INEGI, Mexico, Mexico.

Joyal, E. 1996. The palm has its time: an ethnoecology of Sabal uresana in Sonora, Mexico. Economic Botany 50(4):446-462.

Kates, R. W., W. C. Clark, R. Corell, J. M. Hall, C. C. Jaeger, I. Lowe, J. J. McCarthy, H. J. Schellnhuber, B. Bolin, N. M. Dickson, S. Faucheux, G. C. Gallopin, A. Grübler, B. Huntley, J. Jäger, N. S. Jodha, R. E. Kasperson, A. Mabogunje, P. Matson, H. Mooney, B. Moore, T. O'Riordano, and U. Svedin. 2001. Environment and development: sustainability science. Science 292(5517):641-642.

Kottak, C. P. 2004. An anthropological take on sustainable development: a comparative study of change. Human Organization 63(4):501-510.

Lubchenco, J., A. M., Olson, L. B., Brubaker, S. R., Carpenter, M. M., Holland, S. P., Hubbell, S. A., Levin, J. A., MacMahon, P. A., Matson, J. M., Melillo, H. A., Mooney, C. H., Peterson, H. R., Pulliman, L. A., Real, P. J., Regal, P. G., Risser. 1991. The sustainable biosphere initiative: an ecological research agenda. Ecological Applications 3(4):547-549.

Mangel, M., R. J. Hofman, E. A. Norse, and J. R. Twiss. 1993. Sustainability and ecological research. Ecological Applications 3(4):573-575.

Martínez-Ballesté A., J., Caballero, V., Gama, S., Flores, and, C. Martorell. 2002. Sustainability of 
the traditional management of Xa'an palms by the lowland Maya of Yucatan, México. Pages 381-388 in Ethnobiology and biocultural diversity.

International Society of Ethnobiology, Athens, Georgia, USA.

Martínez-Ballesté, A., C. Martorell, M. Martínez-Ramos, and J. Caballero. 2005.

Applying retrospective demographic models to assess sustainable use: the Maya management of Sabal palms. Ecology and Society 10(2):17. [online] URL: www.ecologyandsociety.org/vol10/iss2/art17/

Padoch, C., and W. D. Jong. 1992. Diversity, variation, and change in Ribereño agriculture. Pages 158-174 in K. H. Redford and C. Padoch, editors. Conservation of neotropical forests: working from traditional resource use. Columbia University Press, New York, New York, USA.

Pulido, M. T., and J. Caballero. 2006. The impact of shifting agriculture on the availability of nontimber forest products: the example of Sabal yapa in the Maya lowlands of Mexico. Forest Ecology and Management 222:399-409.

Rocheleau, D. 1999. Sustaining what for whom? Pages 31-47 in U. L. Hatch and M. E. Swisher, editors. Managed ecosystems: the Mesoamerican experience. Oxford University Press, Oxford, UK.

Ruiz -Perez, M., B., Belcher, R. Achdiawan, M. Alexiades, C. Aubertin, J. Caballero, B. Cambell, C. Clement, T. Cunningham, A. Fantini, H. de Foresta, C. García Fernández, K. H. Gautam, P. Hersch Martínez, W. de Jong, K. Kuster, M. G. Kutty, C. Lopez, M. Fu, M. A. Martínez. 2004. Markets drive the specialization strategies of forest peoples. Ecology and Society 9(2):2-22.

Schmink, M. K., H., Redford, and, C. Padoch. 1992. Traditional peoples and the biosphere: framing the issues and defining the terms. Pages 313 in K. H. Redford and, C. Padoch, editors. Conservation of neotropical forests: working from traditional resource Use. Columbia University Press, New York, New York, USA.

Swart, R., P. Raskin, and J. Robinson. 2002. Critical challenges for sustainability science. Science 297: 1994.

Thompson, R. A. 1976. The winds of tomorrow: social change in a Maya town. Row, Philadelphia, Pennsylvania, USA.
Ticktin, T., P. Nantel, F. Ramírez, and T. Johns. 2002. Effects of variation on harvest limits for nontimber forest species in Mexico. Conservation Biology 16(3):691-705.

Ticktin, T. 2004. The ecological implications of harvesting non-timber forest products. Journal of Applied Ecology 41:11-21.

Vayda, A. P. 1983. Progressive contextualization: methods for research in human ecology. Human Ecology 11(3):265-281.

Yengoyan, A. 1986. Theory in anthropology: on the demise of the concept of culture. Comparative Studies in Society and History 28(2):368-374. 
APPENDIX. Sensitivity matrices for Sabal yapa and Sabal mexicana in two traditional homegardens. High values are shown in boldface. Palm size categories: seedlings (SD); saplings which have no above-ground stems and bifid leaves (SA1), incompletely-divided leaves (SA2), completely-divided leaves (SA3); juveniles with stems of 1-50 cm (J1), 51-100 cm (J2), 101-200 cm (J3) and 201-300 cm (J4); and adults, reproductive individuals with stems of $301-400 \mathrm{~cm}(\mathrm{~A} 1), 401-650 \mathrm{~cm}(\mathrm{~A} 2)$, and $651 \mathrm{~cm}$ or more (A3).

\begin{tabular}{|c|c|c|c|c|c|c|c|c|c|c|c|}
\hline \multirow{2}{*}{$\begin{array}{l}\text { Homegarden-1 } \\
\text { Sabal yapa } \\
\lambda=1.007\end{array}$} & \multicolumn{11}{|c|}{ Sensitivity matrices } \\
\hline & SD & SA1 & SA2 & SA3 & $\mathrm{J} 1$ & $\mathrm{~J} 2$ & $\mathrm{~J} 3$ & $\mathrm{~J} 4$ & A1 & $\mathrm{A} 2$ & A3 \\
\hline SD & 0.045 & 0.023 & & & & & & & 0.000 & 0.000 & 0.000 \\
\hline SA1 & 0.144 & 0.074 & 0.041 & & & & & & & & \\
\hline SA2 & 0.206 & 0.106 & 0.058 & 0.075 & & & & & & & \\
\hline SA3 & & 0.209 & 0.114 & 0.146 & & & & & & & \\
\hline $\mathrm{J} 1$ & & & & 0.314 & 0.151 & & & & & & \\
\hline $\mathrm{J} 2$ & & & & & 0.164 & 0.084 & & & & & \\
\hline $\mathrm{J} 3$ & & & & & & 0.214 & 0.165 & & & & \\
\hline $\mathrm{J} 4$ & & & & & & & 0.180 & 0.065 & & & \\
\hline A1 & & & & & & & & 0.137 & 0.039 & & \\
\hline A2 & & & & & & & & & 0.077 & 0.056 & \\
\hline A3 & & & & & & & & & & 0.442 & 0.116 \\
\hline $\begin{array}{l}\text { Homegarden- } 2 \\
\text { Sabal yapa }\end{array}$ & & & & & & nsitivity & atrices & & & & \\
\hline$\lambda=1.092$ & SD & SA1 & SA2 & SA3 & $\mathrm{J} 1$ & $\mathrm{~J} 2$ & $\mathrm{~J} 3$ & $\mathrm{~J} 4$ & A1 & A2 & $\mathrm{A} 3$ \\
\hline SD & 0.054 & 0.020 & & & & & & & 0.001 & 0.001 & 0.000 \\
\hline SA1 & 0.116 & 0.044 & & & & & & & & & \\
\hline SA2 & 0.258 & 0.097 & 0.048 & 0.083 & & & & & & & \\
\hline SA3 & & 0.160 & 0.080 & 0.136 & & & & & & & \\
\hline $\mathrm{J} 1$ & & & & 0.442 & 0.114 & & & & & & \\
\hline $\mathrm{J} 2$ & & & & & 0.183 & 0.122 & & & & & \\
\hline $\mathrm{J} 3$ & & & & & & 0.204 & 0.133 & & & & \\
\hline $\mathrm{J} 4$ & & & & & & & 0.234 & 0.079 & & & \\
\hline A1 & & & & & & & & 0.154 & 0.147 & & \\
\hline A2 & & & & & & & & & 0.140 & 0.121 & \\
\hline A3 & & & & & & & & & & 0.019 & 0.003 \\
\hline
\end{tabular}




\begin{tabular}{|c|c|c|c|c|c|c|c|c|c|c|c|}
\hline \multirow{2}{*}{$\begin{array}{l}\text { Homegarden- } 1 S \text {. } \\
\text { mexicana } \\
\lambda=1.048\end{array}$} & \multicolumn{11}{|c|}{ Sensitivity matrices } \\
\hline & SD & SA1 & SA2 & SA3 & $\mathrm{J} 1$ & $\mathrm{~J} 2$ & $\mathrm{~J} 3$ & $\mathrm{~J} 4$ & A1 & $\mathrm{A} 2$ & A3 \\
\hline SD & 0.045 & & & & & & & & 0.001 & 0.000 & 0.000 \\
\hline SA1 & 0.505 & 0.040 & & & & & & & & & \\
\hline SA2 & & 0.057 & 0.042 & 0.071 & & & & & & & \\
\hline SA3 & & & 0.053 & 0.089 & & & & & & & \\
\hline $\mathrm{J} 1$ & & & & 0.125 & 0.160 & & & & & & \\
\hline $\mathrm{J} 2$ & & & & & 0.386 & 0.119 & & & & & \\
\hline $\mathrm{J} 3$ & & & & & & 0.231 & 0.116 & & & & \\
\hline $\mathrm{J} 4$ & & & & & & & 0.173 & 0.063 & & & \\
\hline A1 & & & & & & & & 0.077 & 0.113 & & \\
\hline $\mathrm{A} 2$ & & & & & & & & & 0.158 & 0.097 & \\
\hline A3 & & & & & & & & & & 0.127 & 0.116 \\
\hline $\begin{array}{l}\text { Homegarden- } 2 S \text {. } \\
\text { mexicana }\end{array}$ & & & & & & nsitivity & atrices & & & & \\
\hline$\lambda=0.983$ & SD & SA1 & SA2 & SA3 & $\mathrm{J} 1$ & $\mathrm{~J} 2$ & $\mathrm{~J} 3$ & $\mathrm{~J} 4$ & A1 & $\mathrm{A} 2$ & A3 \\
\hline SD & 0.012 & & & & & & & & 0.000 & 0.002 & 0.002 \\
\hline SA1 & 0.125 & 0.012 & 0.008 & & & & & & & & \\
\hline SA2 & & 0.033 & 0.023 & & & & & & & & \\
\hline SA3 & & 0.037 & 0.025 & 0.067 & & & & & & & \\
\hline $\mathrm{J} 1$ & & & & 0.061 & 0.047 & & & & & & \\
\hline $\mathrm{J} 2$ & & & & & 0.051 & 0.063 & & & & & \\
\hline $\mathrm{J} 3$ & & & & & & 0.072 & 0.062 & & & & \\
\hline $\mathrm{J} 4$ & & & & & & & 0.125 & 0.029 & & & \\
\hline A1 & & & & & & & & 0.068 & 0.036 & & \\
\hline A2 & & & & & & & & & 0.051 & 0.579 & \\
\hline A3 & & & & & & & & & & 0.095 & 0.070 \\
\hline
\end{tabular}

